\title{
Kontribusi Pers dalam Mempublikasikan Program Unggulan pada Sekolah Rujukan
}

\author{
Ade Rosad $^{1}$, Saipul Annur ${ }^{2}$, Tutut Handayani, ${ }^{3}$ \\ ${ }^{1,2,3}$ Universitas Islam Negeri Raden Fatah Palembang \\ aderosad@yahoo.com \\ saipulannur_uin@radenfatah.ac.id \\ tututhandayani_uin@radenfatah.ac.id
}

\begin{abstract}
ABSTRACK
The objective of this research is to find out the various programs offered by SMA Negeri 2 Prabumulih. This school has been set as a benchmark by many other schools in Prabumulih. And as well as the contributions made by the press, in building the school's reputation. Additionally, to identify the different factors that may or may not have supported the press publishing the article in Prabumulih City. For this research all the data had obtained through interviews, observation and documentation from the respective school principals of SMA Negeri 2 in Prabumulih. Playing a key role as policy makers in establishing the respective schools. With approval from editors and journalists of Prabumulih Post by using purposive sampling. The subject matter discussed for this research is to determine what are the various programs offered by the school, and how the press may contribute in publishing it. The results of this study reveal that: (1) SMA Negeri 2 Prabumulih, there are six excellent programs in academics and non academics. All the six programs offered by the school had obtained excellent result to it. (2)The flagship programs offered by the school will be more complete when there is the presence of the media coverage. This is what Prabumulih Pos has done as the only local daily print media in Prabumulih City. Contributing by publishing these programs at this school can bring up good reputation in improving qualification of education as well as a reference needed by local authority.
\end{abstract}

Keyword: featured program, referrel school, press, educational rubrik

\footnotetext{
ABSTRAK

Penelitian ini bertujuan untuk mengetahui berbagai program yang ditawarkan oleh SMA Negeri 2 Prabumulih. Sekolah ini telah ditetapkan sebagai media cetak lokal di daerah tersebut. Dan juga kontribusi yang diberikan oleh pers, dalam membangun reputasi sekolah. Selain itu, untuk mengidentifikasi berbagai faktor yang mungkin atau mungkin tidak mendukung pers menerbitkan artikel di Kota Prabumulih. Untuk penelitian ini semua data diperoleh melalui wawancara, observasi dan dokumentasi dari masing-masing kepala sekolah SMA Negeri 2 Prabumulih. Memainkan peran kunci sebagai pembuat kebijakan dalam mendirikan sekolah masing-masing. Dengan persetujuan redaksi dan wartawan Prabumulih Post dengan menggunakan purposive sampling. Pokok bahasan dalam penelitian ini adalah untuk menentukan apa saja program yang ditawarkan oleh sekolah, dan bagaimana pers dapat berkontribusi dalam mempublikasikannya. Hasil penelitian ini mengungkapkan bahwa: (1) SMA Negeri 2 Prabumulih, terdapat enam program unggulan di bidang akademik dan non akademik. Keenam program yang ditawarkan oleh sekolah tersebut semuanya memperoleh hasil yang sangat baik. (2) Program unggulan yang ditawarkan sekolah akan semakin lengkap bila ada liputan media. Inilah yang dilakukan Prabumulih Pos sebagai satu-satunya media cetak harian lokal di Kota Prabumulih. Berkontribusi dengan menerbitkan program-program tersebut di sekolah ini dapat membawa reputasi yang baik dalam meningkatkan kualifikasi pendidikan serta referensi yang dibutuhkan oleh pemerintah daerah.
} 
Kata kunci: Program Unggulan, Sekolah Rujukan, Pers, Rubrik Pendidikan PENDAHULUAN

Kaitannya dengan dunia pendidikan, pers selalu berperan aktif, karena salah satu fungsi pers adalah pendidikan. Selain memberikan informasi, penyebaran pengetahuan baru, pers juga tentunya memiliki fungsi mendidik dan menghibur (Hannah Mahfuzhah and Anshari Anshari, 2018: 137-49). Dalam mensosialisasikan program unggulan sekolah, keterlibatan pers sangat signifikan untuk turut mencerdaskan kehidupan bangsa melalui informasi yang sehat dan akuntabel. Kehadiran pers di tengah masyarakat tentunya memberi dampak positif untuk sarana informasi masyaraat. Begitu juga bagi sekolah rujukan, pers memberi dukungan melalui penyebaran informasi dalam rangka mendorong peningkatan kualitas pendidikan. Harus diakui, persoalan pendidikan masih sangat komplek. Butuh peran aktif kita semua dalam mewujudkan pendidikan yang berkualitas, berdasarkan tujuan pendidikan Nasional.

Disinilah tantangan lembaga pendidikan untuk terus berbenah, berinovasi secara kreatif, dalam upaya peningkatan mutu pendidikan. Sekolah yang berorientasi pada mutu pendidikannya, tidak hanya menguntungkan sekolah itu sendiri, melainkan akan berdampak positif pada dunia pendidikan secara umum. Dibutuhkan keterbukaan dan transparansi khususnya bidang informasi, agar publik bisa mengakses berbagai persoalan hal yang ada, dimana ada hal-hal yang memang membutuhkan peran masyarakat untuk mencarikan solusi yang dihadapi lembaga pendidikan. Oleh sebab itu, sekolah harus mampu membangun kerja sama yang baik dengan masyarakat.

Melalui peran media massa, setiap orang, kelompok maupun lembaga, dapat terlibat dalam pemberian informasi untuk sampai pada penerima inforamsi (Ade Putranto Prasetyo, 2020). Hal ini diharapkan dapat dimanfaatkan lembaga pendidikan untuk berperan aktif, bersinergi menyampaikan pesan-pesan positif melalui media dalam hal ini pers sehingga dapat diketahui publik. Kata pers berasal dari bahasa Belanda yang artinya menekan. Arti yang sama ditemukan juga dalam bahasa Inggris yaitu press. Demikian yang diungkapkan Ade Putranto. Makna menekan atau mengepres berasal dari pengertian menekan atau mengepres berawal dari pengertian perantara berkomunikasi antar individu dalam sebuah masyarakat melalui mekanisme percetakan, yang kemudian berkembang menjadi istilah pres hingga mengalami perluasan makna yang berhubungan dengan kegiatan jurnalistik, yang tidak sebatas junalistik cetak melainkan merambah hingga juralistik elektronik. Pengertian pers menurut Undang-Undang RI Nomor 40 Tahun 1999 ialah lembaga sosial dan wahana komunikasi massa yang bertugas untuk melaksanakan kegiatan jurnalistik 
meliputi mencari, memperoleh, memiliki, menyimpan, mengolah, serta menyampaikan informasi baik dalam bentuk tulisan, suara, gambar, suara dan gambar, serta data grafik, maupun dalam bentuk lainnya dengan menggunakan media cetak, elektronik, dan segala jenis saluran yang tersedia (Ade Putranto Prasetyo, 2020). Sementara menurut Leksikon, pers bearti usaha percetakan dan penerbitan, usaha pengumpulan dan penyiaran berita, penyiaran berita melalui surat kabar atau media cetak (Kamaruddin Kamaruddin, 2018: 127-46).

Dari beberapa pengertian di atas peneliti simpulkan bahwa pers sebagai sarana komunikasi massa yang dikemas dalam bentuk penyiaran baik melalui media cetak, elektronik maupun internet untuk dapat diketahui masyarakat. Pers sebelum dinikmati publik harus memenuhi kaidah jurnalistik berdasarkan Undang-Undang Nomor 40 Tahun 1999, dengan menjaga asas praduga tak bersalah dan keberimbangan. "Mengingat fungsi pers menyampaikan informasi kepada masyarakat, maka memiliki relevansi dalam memberikan kontribusinya dalam kehidupan berbangsa dan bernegara. Kontribusi dimaksud bermakna sumbangan atau bisa dikatakan memberikan andil (Kamus Besar Bahasa Indonesia, 2011).

Dari kata "kontribusi", maka dinilai tepat jika dikaitkan dengan pers. Dimana kontribusi pers dalam bidang pendidikan sangat berpengaruh dalam memberi informasi kepada masyarakat luas. McQuail dalam bukunya Mass Communikations Theories, ia menyebut ada beberapa prespektif tentang peran maupun kontribusi pers diantaranya ialah sebagai window on and experience. Dimana media dipandang sebagai jendela yang memungkinkan bagi khalayak melihat apa yang sedang terjadi di luar sana. Bisa dikatakan juga bahwa media merupakan sarana belajar untuk mengetahui berbagai peristiwa (Aria Aditya Setiawan Aria Aditya Setiawan, (2013): 39-48). Dari pengertian tersebut jelas, bahwa pers memiliki peran penting dalam melihat dan mengetahui sesuai yang baru.

Pers yang berperan mempublikasikan konten berita kepada publik, dapat dihasilkan dari berbagai sumber. Salah satunya lembaga pendidikan yaitu sekolah. Sekolah merupakan suatu lembaga tempat dilaksanakannya proses pendidikan atau pembelajaran. Teguh Triwiyanto mendefinisikan sekolah adalah kelompok layanan pendidikan yang menyelenggarakan pendidikan pada jalur formal, non-formal, dan informal pada setiap jenjang dan jenis pendidikan (Manap Somantri, (2020): 92-109). Dalam menjalankan program pendidikannya sekolah tentunya berlomba-lomba memberikan pelayanan terbaik kepada anak didiknya dengan pendidikan berkualitas. 
Di sinilai peran kepala sekolah. Dimana kepala sekolah sebagai nahkoda lembaga pendidikan dituntut memiliki ide dan gagasan untuk memajukan sekolah, sehingga sekolah yang dipimpinnya dapat tampil beda dengan lainnya. Tidak hanya itu, kemampuan kepala sekolah dalam membangun sekolah unggul atau bermutu sangat dibutuhkan. Sehingga masyarakat sebagai konsumen pendidikan akan merasa puas dengan layanan pendidikan yang diberikan kepada anaknya. Pentingnya membuat program unggulan sekolah, maka dibutuhkan perencanaan yang matang. Perencanaan sendiri merupakan pemilihan tujuan jangka pendek, jangka panjang serta merencanakan taktik dan strategi untuk mencapi tujuan tersebut (Prasetyo Budi Utomo, Mulyadi Eko Purnomo, and Mgs Nazarudin, (2021): 83-97). Untuk memperlancar kegiatan sekolah, kepala sekolah bisa memberdayakan bagian humas untuk membuat program kehumasan agar mempermudah komunikasi dengan pers. Menurut Rahutomo dalam Jurnal Media Publikasi Humas dalam Pendidikan yang ditulis Hannah Mahfuzhah dan Anshari mengatakan, humas bekerja, mendukung pembinaan dan pembangun upaya yang saling menguntungkan melalui komunikasi, pengertian, penerimaan, dan kerja sama yang baik antara organisasi dengan publiknya (Mahfuzhah and Anshari). Atas dasar itulah, sekolah harus memiliki program-program unggulan berkualitas sehingga mampu mengantarkan menjadi sekolah rujukan di daerahnya.

Program dimaksud adalah program pendidikan atau pembelajaran. Dimana kata program bearti rancangan yang diproyeksikan pada kualitas pendidikan sekolah. Program unggulan pada lembaga pendidikan akan mampu mengantarkan menjadi sekolah rujukan. Sekolah dalam melaksanakan pendidikan bermutu harus seirama dengan apa yang diprogramkan pemerintah di bidang pendidikan. Upaya ini sebagai bentuk komitmen pemerintah agar standar dan kualitas pndidikan di Indonesia ada kesimbangan dan pemerataan di seluruh daerah. Mulyasa mengatakan "pendidikan bermutu adalah pendidikan yang mampu melakukan proses pematangan kualitas peserta didik yang dikembangkan dengan cara membebaskan peserta didik dari ketidaktahuan, ketidakmampuan, ketidakberdayaan, dan dari buruknya akhlak dan keimanan (Somantr).

Dalam konteks mutu pendidikan ini, pemerintah pusat maupun daerah wajib memberikan pelayanan endidikan bermutu yang tertuang dalam Permendikbud Nomor 28 tahun 2016 tentang Sistem Penjaminan Mutu Pendidikan (SPMP) Dasar dan Menengah (Somantr). Dimana Keputusan Menteri Pendidikan dan Kebudayaan (Kemendikbud) mendorong setiap satuan pendidikan untuk melaksanakan Sistem Penjaminan Mutu Pendidikan (SPMI) agar dapat mencapai Standar Nasional Pendidikan (SNP). Dalam 
Permendikbud sebagai dasar hukum dalam mewujudkan sekolah rujukan, yang bearti sebuah lembaga sebagai tempat belajar dan mengajar yang dijadikan sebagai sumber informasi, sumber acuan dan referensi mengenai hal-hal yang berhubungan dengan perkembangan dunia pendidikan (Somantr). Kehadiran sekolah rujukan di kabupaten/kota sangat menguntungkan sekaligus membanggakan. Karena akan menjadi acuan atau contoh sekolah lainnya.

Atas dasar tersebut, peneliti memandang perlu melakukan penelitian pada sekolah rujukan di Kota Prabumulih, yaitu SMA Negeri 2 Prabumulih. Peneliti akan memfokuskan pada Kontribusi Pers dalam Mempublikasikan Program Unggulan pada Sekolah Rujukan di SMA Negeri 2 Kota Prabumulih. Dimana SMA Negeri 2 Prabumulih memiliki enam program unggulan diantaranya, organisasi ekstra kulikuler (eskul), Penerapan Pola Hidup Seratus Persen (PHSP), Ekskul Sekola Siaga Kependudukan (SSK), Jurnalistik, Pramuka, Buletin Wonderful, selain itu sekolah ini juga memiliki Kantin Sehat dan Jujur (Somantr). Di bidang literasi, SMA Negeri 2 Prabumulih memiliki perpustakaan yang representatif dan masuk nominasi pada lomba Perpustakaan se-Sumatera Selatan (Sumsel).

Dari kondisi di atas, peneliti berpendapat butuh kerja sama yang lebih maksimal antara sekolah khususnya bagian humas dengan pers. Kehadiran pers tentunya sangat penting, karena fungsi pers juga sebagai sarana pendidikan bagi masyarakat. Pers bertanggung jawab memberikan informasi yang benar dan dapat dipertanggung jawabkan, dengan begitu sekolah tidak perlu ragu memberikan informasi kepada pers. Dengan sama-sama mempunyai tanggung jawab dalam mencerdaskan bangsa, maka sangat jelas bahwa sekolah dan pers harus bergandengan tangan dalam rangka mendukung program peningkatan mutu pendidikan Nasional. Sekolah tidak perlu takut atau ragu menyampaikan informasi, karena semuanya sudah diatur dalam Undang-Undang Nomor 40 Tahun 1999 tentang Pers.

Melihat fonomena ini, tentunya menjadi perhatian media massa di kota tersebut. Tidak sedikit pers mengangkat keunggulan dan prestasi sekolah ini. Baik prestasi bidang akademik dan non-akademik. Seperti yang dilakukan media lokal di Kota Prabumulih yaitu Harian Umum Prabumulih Pos. Sebagai koran lokal, Prabumulih Pos tentunya lebih dekat dengan kelembagaan baik pemerintah maupun swasta di Kota Prabumulih, termasuk diantaranya dengan lembaga pendidikan. Banyak karya jurnalistik harian ini dalam mengangkat berita-berita yang berkaitan dengan pendidikan. Hal ini sangat relefan dengan kehadiran Prabumulih Pos sebagai lembaga pers yang ikut andil dalam memberikan informasi bidang pendidikan. Terlebih, Prabumulih Pos memiliki rubrik khusus Pendidikan 
setiap harinya. Dengan demikian ada kontribusi pers dalam mempublikasikan program unggulan pada sekolah rujukan di Kota Prabumulih. Agar lebih sinergi dan mendukung tugas jurnalistik, sekolah rujukan harus mampu memberdayakan humas sekolah untuk berperan aktif menyampaikan informasi-informasi melalui pers agar diketahui publik. Tentunya, dengan dukungan dan arahan dari kepala sekolah sebagai penangung jawab. Dalam penelitian ini, peneliti ingin membuktikan apakah ada kontribusi pers dalam mempublikasikan program unggulan pada sekolah rujukan di Kota Prabumulih, yaitu di SMA Negeri 2. Oleh karena itu, peneliti tertarik meneliti apa saja program unggulan di sekolah tersebut, strategi sekolah dalam menentukan bentuk program unggulan, dan bagiamana cara sekolah mengimplementasikan program unggulan sekolah dan mempublikasikannya ke media massa.

\section{TINJAUAN PUSTAKA}

Merujuk pada Undang-Undang RI Nomor 40 Tahun 1999 Pasal 1 menyatakan bahwa Pers adalah lembaga sosial dan wahana komunikasi massa yang melaksanakan kegiatan jurnalistik meliputi mencari, memperoleh, memiliki, menyimpan, mengolah, dan menyampaikan informasi baik dalam bentuk tulisan, suara, gambar, suara dan gambar, serta data dan grafik maupun dalam bentuk lainnya dengan menggunakan media cetak, media elektronik, dan segala jenis saluran yang tersedia (UU Pers No 40:1999). Pengertian Pers juga dikemukakan Adji, dalam buku Ade Putranto Prasetyo yang menyebut pers dibagi dalam arti sempit dan luas. Pers dalam arti sempit adalah penyiaran pikiran, gagasan berita dalam bentuk kata tertulis. Sementara "pers dalam arti luas memiliki pengertian memasukan di dalamnya semua media massa komunikasi yang memancarkan pikiran serta perasaan baik dengan kata-kata tertulis maupun dengan kata-kata lisan (Ade Putranto Prasetyo).

Arti dari program adalah rancangan. Saifuddin Anshari mendefinisikan program adalah daftar terinci mengenai cara dan usaha yang akan dilaksanakan. Sementara unggulan, berasal dari kata unggul yang bermakna lebih tinggi, lebih baik, lebih bermutu (Mahfuzhah and Anshari). Jika menjadi kata unggulan bearti lebih diutamakan atau lebih diunggulkan. Di lain pihak, kata "unggul seperti halnya yang digunakan dalam istilah-istilah "sekolah unggulan", "produk unggulan", dan sebagainya. Umumnya telah diterima masyarakat mengandung nilai-nilai positif yang bermakna nilai lebih pada objek tertentu. Dengan begitu program ungulan adalah suatu rangkaian langkah-langkah yang dilaksanakan dengan 
urutan tertentu untuk mencapai keunggulan dalam keluaran (output) pendidikannya. Program Unggulan juga dapat dikatakan adalah suatu rangkaian langkah-langkah yang dilaksanakan dengan urutan tertentu untuk mencapai suatu tujuan tertentu. Sementara Kontribusi dimaksud bermakna sumbangan atau bisa dikatakan memberikan andil (Mahfuzhah and Anshari). Dari dua kata tersebut, memberi arahan kepada peneliti untuk nantinya dapat berpedoman pada teori-teori dalam melaksanaan penelitin di lapangan.

Kemendikbud sendiri mendefinisikan "sekolah rujukan yaitu sekolah yang telah memiliki akreditas A, memajukan ekosistem pendidikan, memiliki lingkungan dan iklim sekolah yang nyaman serta menerapkan pendidikan karakter yang dapat dijadikan panutan atau contoh untuk sekolah yang ada di sekitarnya (Husnita Usman, 2020). Selanjutnya, pada sekolah rujukan adalah sekolah yang telah memenuhi 8 SNP dan mempunyai kemampuan untuk mengimbaskan kepada sekolah disekitarnya dengan tujuan meningkatkan dan menyamaratakan mutu pendidikan di Indonesia. Dimana 8 standar dimaksud adalah standar isi, standar kompetensi lulusan, standar proses pendidikan, standar sarana dan prasarana, standar pengelolaan, standar pembiayaan pendidikan, standar peilaian pendidikan dan standar pendidik dan tenaga kependidikan.

\section{METODE}

Dilihat dari segi tujuan pendidikan maka penelitian ini termasuk pada penelitian lapangan. Dimana hasil penelitian ini dapat digunakan sebagai rujukan sekaligus pertimbangan, dalam meningkatkan mutu pendidikan yang berpengaruh pada peningkatan kualitas mutu pendidikan pada sekolah rujukan di Kota Prabumulih, dan memberi dampak positif bagi kemajuan sekolah sekitar. Penelitian ini juga diharapkan dapat menjadi bahan referensi pengetahuan bagi dunia pers pada umumnya, dan Koran Prabumulih Pos pada khususnya. Dari segi tujuan dan jenis data, penelitian mengunakan pendekatan deskriftif kualitatif. Data akan diolah, diterima dari informan, seperti pemimpin redaksi Prabumulih Pos, dan redaktur rubrik pendidikan, Kepala SMA Negeri 2 Prabumulih dan informan yang terkait dengan penelitian ini. Dengan begitu, penelitian ini akan lebih komprehensif sesuai dengan harapan.

Mengingat penelitian ini adalah penelitian kualitatif, maka penelitin akan menitik beratkan pada data-data kualitatif, yang tidak megngunakan perhitungan. Dimana lebih menekankan pada sumber data lapangan yang didukung data otentik lainnya. Berdasarkan definisi Sugiono mengatakan "penelitian kualitatif adalah penelitian yang digunakan untuk 
meneliti pada kondisi objek ilmiah dengan peneliti sebagai instrumen kunci, teknik pengumpulan data dilakukan secara triangulasi (gabungan), analisis data bersifat induktif dan hasil penelitian kualitatif lebih menekankan pada makna dari generalisasi (Lexy Moloeng, 2016). Penelitian ini adalah penelitian lapangan yang bersifat analisis kualitatif dengan menggunakan kata-kata deskriptif, karena penelitian yang dilalui dengan menafsirkan, mendeskripsikan data, mengklarifikasi data, yang kemudian dilanjutkan dengan interprestasi dan yang terakhir adalah diadakannya ekstrapolasi yang menyangkut makna dan hasil penelitian yang dicapai sebagai sumbangan pemikiran. Informan (narasumber) penelitian adalah seseorang yang memiliki informasi mengenai objek penelitian ini. Informan dalam penelitian ini yaitu berasal dari wawancara langsung yang disebut sebagai narasumber. "Dalam penelitian ini menentukan informan dengan menggunakan teknik purposive sampling atau teknik pengambilan sampel sumber data dengan pertimbangan tertentu, yaitu orang yang paling tahu tentang apa yang kita harapkan, atau orang yang ahli (Sugiyono).

\section{HASIL PEMBAHASAN}

\section{Hasil Penelitian}

\section{Bentuk Program Unggulan pada Sekolah Rujukan di Kota Prabumulih}

Sekolah pada setiap jejang pendidikan, senantiasa melakukan inovasi dalam melaksanakan kegiatan belajar mengajar. Baik akademik maupun non akademik. Terutama pada jenjang pendidikan SMA. Tidak heran, apabila setiap SMA selalu berkompetisi dalam menonjolkan bentuk program unggulan. Karena tidak dipungkiri, jika ada program unggulan sebagai ciri khas sekolah, maka akan menjadi nilai jual sekaligus brand sekolah itu sendiri. Inilah yang terus dilakukan sejumlah sekolah, baik swasta maupun negeri. Terutama sekolah rujukan untuk terus bersaing dalam meningkatkan mutu pendidikan hingga mendapat pangakuan baik dari pemerintah maupun masyarakat sebagai konsumen pendidikan.

Kehadiran program unggulan bertujuan meningkatkan mutu dan kualitas pendidikan di era 4.0 ini. Dimana hampir semua proses belajar mengajar terkoneksi dengan digitalisasi. Tentunya kondisi ini membutuhkan kemampuan manajerial dan sekaligus operatur yang siap pada sekolah tersebut. Sehingga, baik guru maupun siswa lebih terlatih dalam memanfaatkan informasi teknologi (IT) yang ada. Untuk mencapai keberhasilan dari program ungulan tersebut diperlukan program yang terencana yang diawali dari 
perecanaan, proses, kemampuan manajerial kepala sekolah, pengawasan hingga evaluasi program. Selain itu, kepala sekolah dituntut mampu berkomunikasi dengan warga sekolah, stakeholder, masyarakat dan pemerintah, selanjutnya untuk mendukung implementasi program unggulan dibutuhkan pula dukungan publikasi media massa sebagai wujud eksistensi dan penyampaian informasi program unggulan pendidikan sekolah kepada masyarakat.

\section{Program Unggulan SMA Negeri 2 Prabumulih}

SMA Negeri 2 Prabumulih merupakan sekolah rujukan yang ditetapkan Pemerintah Provinsi Sumatera Selatan (Sumsel) melalui Dinas Pendidikan Nasional. Sebagai sekolah rujukan, tentunya SMA Negeri 2 Prabumulih dinilai memiliki keunggulan sekaligus prestasi membanggakan tingkat kota, provinsi, nasional dan internasional. Prestasi tersebut baik bidang akademik maupun non akademik yang dibuktikan dengan penghargaan dan tropi sehingga bisa didokumenkan. Menurut informan KS 2, program ungulan sekolah telah memberikan kontribusi baik berupa prestasi guru maupun siswa dibuktikan dengan penghargaan dan tropi. Prestasi tersebut memberi dampak positif bagi sekolah (KS, "Wawancara" (SMA Negeri 2 Prabumulih, 2021). Sebagai sekolah rujukan di Kota Prabumulih, SMA Negeri 2 Prabumulih terus meningkatkan kualitas mutu pendidikan yang dilaksanakan. Dalam mempertahankan statusnya sebagai sekolah rujukan, tentunya tidak mudah.

Butuh komitmen bersama dari warga sekolah untuk terus mempertahankannya. "Mempertahankan eksistensi sebagai sekolah rujukan itu tidak mudah. Lebih mudah mengejar dari pada mempertahankan. Ini merupakan tantangan warga sekolah. Oleh karena itu, sekolah terus membangun komunikasi baik dengan masyarakat dalam hal ini komite (KS, "Wawancara" (SMA Negeri 2 Prabumulih, 2021). Dengan melibatkan semua komponen guna mendukung program sekolah sangat penting, untuk itu sekolah terus membangun keterbukaan dalam setiap rencana strategis, sebelum diimplementasikan menjadi program sekolah. Khususnya yang berkaitan dengan prasarana sekolah. Dalam hal program pendidikan, ada enam bentuk program unggulan SMA Negeri 2 Prabumulih sebagai berikut:

1. Organisasi Ekstra Kurikuler (Ekskul)

SMA Negeri 2 Prbaumulih sangat aktif dalam melaksanakan kegiatan ekskul. Apalagi kegiatan tersebut mendapat dukungan penuh dari sekolah, khususnya kepala sekolahnya. Dimana ada 22 ekskul yang dilaksanakan di SMA Negeri 2 Prabumulih ini. 


\section{Penerapan Pola Hidup Seratus Persen (PSHP)}

Penerapan Pola Hidup Seratus Persen atau PSHP merupakan salah satu program unggulan SMA Negeri 2 Prabumulih. Program ini menitik beratkan untuk mencegah sejak dini penyalahgunaan narkoba di kalangan pelajar. Dimana SMA Negeri 2Prabumulih berkomitmen, sehat tidak hanya jasmani, tetapi juga secara rohani. Oleh karena itu, sekolah ini mencanangkan perang terhadap narkoba.

3. Sekolah Siaga Kependudukan (SSK)

SMA Negeri 2 Prabumulih merupakan satu-satunya sekolah di Kota Prabumulih yang memiliki ekskul Sekolah Siaga Kependudukan (SSK). Sekolah Siaga Kependudukan ini adalah sekolah yang mengintegrasikan pendidikan kependudukan dan KB (Keluarga Berencana) ke dalam mata pelajaran sebagai pengayaan materi pembeajaran. Sebagai pendukung program ini, SMA Negeri 2 Prabumulih menyiapkan pojok kependudukan sebagai sumber belajar bagi siswa dalam membentuk generasi keluarga berencana, serta dapat memahami isu kependudukan.

\section{Jurnalistik dan Buletin Wonderful SMANDA}

Program Jurnalistik dan Buletin Wonderful SMANDA merupakan program unggulan, karena satu-satunya sekolah di Kota Prabumulih yang membuat, mencetak, dan mempunyai majalah milik sekolah. Untuk saat ini saja, telah menerbitkan 4 edisi majalah yang isinya merangkum berbagai kegiatan SMA Negeri 2 Prabumulih.

5. Pramuka

SMA Negeri 2 Prabumulih juga merupakan satu-satunya SMA se Kota Prabumulih yang ekstra kulikuler wajib yaitu Pramuka. Ekskul yang satu ini telah terakreditasi. Dimana gugus depan putra dan putri mendapatkan predikat Akreditasi A secara nasional. Ekskul pramuka ini telah banyak membawa nama baik sekolah baik tingkat kota, provinsi hingga nasional.

6. Kantin Sehat dan Jujur Al-Barokah SMA Negeri 2 Prabumulih

Kantin Sehat dan Jujur, merupakan kantin yang baru dibangun pada bulan Juli 2020 dan selesai dibangun Desember 2020. Pembangunan kantin ini menggunakan dana melalui pola swadana dari seluruh warga sekolah. Tujuan dibangunnya kantin ini untuk memberikan fasilitas mempuni untuk seuruh warga SMA Negeri 2 Prabumulih, dengan disesuaikan sekolah ramah anak. Menurut informan KS 2, kantin ini dilengkapi dengan CCTV, water plumbing, sink, dengan kapasitas kantin yang dapat menampung 120 peserta didik. Dimana kantin ini merupakan kantin dengan ukuran yang luas terintegrasi 
dengan sarana baca yang tersedia di Perpustakaa (KS, 2021). Makanan dan minuman yang tersedia juga tidak mengunakan bahan pengawet. Dalam hal transaksi, siswa bebas mengambil makanan, membayar dan mengambil kembalian sesuai dengan tempat yang disediakan. Hal ini memberi edukasi sikap jujur pada siswa walau tidak diawasi orang lain.

\section{Kontribusi Prabumulih Pos dalam Mempublikasikan Program Unggulan pada Sekolah Rujukan di Kota Prabumulih}

Harian Prabumulih Pos merupakan media lokal satu-satunya dan pertama di Kota Prabumulih. Sejak terbit perdana 2006 lalu, Prabumulih Pos telah banyak memberi kontribusi rubrikasi pendidikan sebagai salah satu rubrik primadona pembaca. Menurut informan AZ, "Khusus rubrik pendidikan selalu diutamakan, karena rubrik ini tidak pernah ibur, keuali jika ada iklan yang menginginkan di halaman 3 (halaman pendidikan). Jadi Prabumulih Pos, secara kontribusi telah berbuat maksimal dalam rangka penyampaian informasi pendidikan kepada masyarakat (AZ, "Wawancara" (Pemimpin Redaksi Prabumulih Pos, 2021). Rubrik pendidikan memiliki keunguglan tersendiri, salah satunya segmen pembacanya jelas, yaitu sekolah, praktisi pendidikan, perguruan tinggi, dan pemerintah. Ini semua tidak terlepas dari peran serta tim redaksi untuk menjadi rubrik pendidikan selalu eksis dengn pemberitaan terbaru. Prabumulih Pos terus menjalin kerja sama dengan lembaga pendidikan yang ada di Prabumulih, selain menjadi mitra, keberadaan lembaga pendidikan juga sekaligus sebagai sumber berita. Hingga saat ini, kerja sama terus terjalin baik tanpa mengurangi sisi kritis Prabumulih Pos sebagai kontrol masyarakat (AZ, "Wawancara" (Pemimpin Redaksi Prabumulih Pos, 2021). Program unggulan pada sekolah rujukan tidak luput dari pemberitaan Prabumulih Pos, seperti halnya di SMA Negeri 2 Prabumulih pada PDF koran berikut:

a. Prabumulih Pos Edisi 10 Juni 2021 pada Halaman Pertama (1). Judul: "Kembangkan Ekosistem Sekolah Kondusif: Fokus pada 8 Program Unggulan’. Pada edisi tersebut, Prabumulih Pos mempublikasikan program unggulan SMA Negeri 2 Prabumulih dengan narasumber Kepala SMA Negeri 2 Prabumulih. Pada kesempatan tersebut, melaksanakan Talkshowdi Radio Pentas 98.7 FM Prabumulih, yang menceritakan secara gamblang program unggulan SMA Negeri 2 Prabumulih sebagai sekolah rujukan nasional di Prabumulih. Dimana kegiatan itu, dipublikasi oleh koran Prabumulih Pos.

b. Prabumulih Pos Edisi 16 April 2021 pada Halaman 3. Judul: "Komitemen Dukung Budaya Literasi Indonesia”. Pada edisi ini, Prabumulih Pos mempublikasikan program 
unggulan SMA Negeri 2 Prabumulih bidang literasi, yang dipusat di Perpustakaan Man Jadda Wa Wajada. Perpustakaan ini terhubung dengan Kantin Sehat dan Jujur, artinya menjadi satu kesatuan. Dalam mempublikasikan berita ini, Prabumulih Pos menjadikan kepala SMA Negeri 2 Prabumulih Hj. Eva Yustina, S.Pd, M.Pd sebagai narasumber. Liputan ini sangat berguna untuk mendorong siswa cinta membaca, dan diharapkan memiliki imbas kepada sekolah di sekitar SMA Negeri 2 Prabumulih, sebagai sekolah rujukan.

c. Prabumulih Pos Edisi 15 Maret 2021 pada Halaman 3. Judul: "Kantin Sehat dan Jujur Masuk Program Unggulan:Tunggu Lesensi BPOM dan Sertifikasi Halal MUI”. Sebagai salah satu program unggulan, Kantin Sehat dan Jujur memberi pesan edukasi pentingnya makanan sehat tanpa bahan pengawet, yang harus diperhatikan siswa. Selain itu, dalam jual beli dibutuhkan kejujuran bertransaksi, oleh karena itu kantin ini tidak menempatkan kasir, melainkan siswa sendiri yang mengambil makanan, membayar hiungga mengambil kembaliannya pada kotak yang disediakan kantin. Berita ini menjadikan kepala SMA Negeri 2 Prabumulih Hj. Eva Yustina, S.Pd, M.Pd sebagai narasumber langsung untuk memberi pemahaman pada warga sekolah.

d. Prabumulih Pos Edisi 10 Maret 2021 pada Halaman 3. Judul: "Miliki 6 Program Unggulan, Terus Kejar Prestasi”,

Sebagai sekolah rujukan di Kota Prabumulih, SMA Negeri 2 Prabumulih memiliki 6 program unggulan. Baik akademik maupun non akademik. Prabumulih Pos menilai menarik untuk dipublikasikan, agar menjadi contoh bagi sekolah lainnya. Karena tujuan dari sekolah rujukan adalah menjadi contoh sekolah di sekitarnya, Hj. Eva Yusnita, S.Pd, M.Pd selaku kepala sekolah menyampaikan secara detail, terkait implementasi sekaligus harapan agar 6 program ungulan tersebut dapat berjalan dengan baik di sekolah yang dipimpinnya. Untuk mewujudkan itu semua, harus memeggang teguh sikap disiplin dan kerja sama seluruh warga sekolah.

\section{PEMBAHASAN}

Kehadiran sekolah rujukan di tengah masyarakat memberi dampak positif dalam peningakatan kualitas pendidikan. Tidak hanya mendorong sekolah secara kompetitif meningkatkan mutu dan kulaitasnya, melainkan masyarakat juga tergerak untuk menyekolahkan putra dan putrinya di sekolah berkualitas. Walaupun untuk masuk sekolah rujukan harus melalui seleksi ketat dengan nilai rata-rata minimal 80,0, artinya kompetisi 
tidak hanya terlihat pada sekokalh melainkan juga pada calon peserta didik baru. Dengan seleksi ketat yang dilakukan pada saat pendaftaran, maka pada prosesnya selama menjalani pendidikan di sekolah rujukan akan sesuai dengan harapan.

Dimana sekolah unggul adalah sekolah yang mampu mengembangkan kemampuan peserta didik menjadi unggul, tidak saja pada dimensi akademik semata tetapi juga pada pertumbuhan optimal kreativitasnya, dan ini harus didukung dengan sumber daya yang ada di sekolah dalam mewujudkan keunggulan dari program sekolah (AZ, "Wawancara" (Pemimpin Redaksi Prabumulih Pos, 2021). Menjadi sekolah unggul yang saat ini berubah menjadi sekolah rujukan tentunya tidak mudah. Seperti halnya yang terjadi pada SMA Negeri 2, sekolah ini harus melalui tahapan verifikasi dari Tim Dinas Pendidikan (Disdik) Provinsi Sumatera Selatan. Sistem penilain mengacu pada 8 Standar Pendidikan Nasional (SPN), sesuai dengan Peraturan Pemerintah (PP) Nomor 32 Tahun 2013 dan PP Nomor 13 Tahun 2015 (Usman).

Dimana 8 standar SNP diantaranya (1) Standar Kompetensi Lulusan (2) Standar Isi (3) Standar Proses (4) Stanadar Penilaian (5) Standar Pendidik dan Tenaga Kependidikan (6) Standar Sarana dan Prasarana (7) Standar Pengelolaan dan (8) Standar Pembiayaan. Setelah delapan SPN terpenuhi, maka sekolah rujukan harus melakukan inovasi agar apa yang diprogramkannya dapat memberi contoh pada sekolah sekitarnya. Karena tujuan dari sekolah rujukan adalah memberi dampak bai pada sekolah yang berdampingan dengannya dan masyarakat sekitar melalui program ungulan sekolah.

Untuk mewujudkan program unggulan dibutuhkan komitmen bersama dari warga sekolah dan disiplin yang tinggi. Tanpa dua hal itu, maka sebaik apapun program yang dirancang tidak akan berjalan maksimal. Inilah yang dipeggang teguh oleh SMA Negeri 2 dan SMA Negeri 3 Prabumulih yang ditetapkan sebagai sekolah rujukan tahun pelajaran 2021/2022 berdasarkan Surat Keputusan (SK) Nomor: 420/0103/SMA.1/Disdik.SS/2021 Perihal Sekolah Rujukan tahun Pelajaran 2021/2022 dikeluarkan oleh Dinas Pendidikan Provinsi Sumatera Selatan (Riza Fahlevi, 2021). Kedua sekolah selain terus membenahi dan meningkatan infrastruktur sekolah, tentunya juga mengimplementasikan program unggulan yang disesuaikan dengan kondisi pandemi Covid-19yang sedang melanda tidak hanya dunia pendidikan, melainkan semua sektor.

Kontribusi pers dalam mempublikasikan program unggulan sekolah rujukan, tentunya seirama dengan fungsi pers dalam bidang pendidikan. Hal tersebut mengingat media massa atau pers banyak menyajikan hal-hal yang bersifat mendidik. Dimana "Fungsi mendidik 
dari media massa adalah melalui pengajaran nilai, etika, serta aturan-aturan yang berlaku kepada komunikan yang menikmati sajian dari media massa tersebut (Ade Putranto Prasetyo). Selain itu menurut Widodo fungsi pers salah satu fungsi pers adalah sebagai pendidik, melalui berbagai macam tulisan atau pesan-pesan yang diberikannya, pers bisa mendidik masyarakat pembacanya (Kukrit Suryo Wicaksono). Dari pengertian di atas, maka pers memiliki peran penting untuk turut membantu mencerdaskan masyarakat melalui informasi yang cerdas, sehat dan jauh dari hoax atau berita bohong. Sesuai dengan pengertian di atas, pers dalam penelitian ini adalah Prabumulih Pos sebagai media cetak di Kota Prabumulih telah berkontribusi dalam mempublikasikan program unggulan sekolah rujukan di Kota Prabumulih, yang telah dijabarkan dalam pembahasan sebelumnya. Degan begitu, peran Prabumulih Pos secara nyata telah ikut andil dalam mempublikasikan informasi pendidikan berdasarkan kode etik jurnalistik dan kaedah-kaedah yang berlaku di masyarakat.

\section{KESIMPULAN}

Berdasarkan hasil analisis data dari pembahasan di atas, maka dapat diambil simpulan bahwa bentuk program unguglan pada sekolah rujukan di Kota Prabumulih ada persamaan, dan juga ada perbedaan baik bidang akademik maupun non akademik. Dimana SMA Negeri 2 Prabumulih memiliki 6 program unggulan. SMA Negeri 2 Prabumulih didukung oleh kepala sekolah berprestasi, dan perstasi siswa, guru, dan sekolah yang menjadikan sekolah tersebut tetap menjadi sekolah favorit di Kota Prabumulih. Kontribusi pers dalam mempublikaiskan program unggulan sekolah rujukan seirama dengan fungsi pers bidang pendidikan. Dimana pers dalam hal ini Koran Prabumulih Pos bertanggung jawab mencerdaskan masyarakat melalui publikasi yang cerdas, sehat, bermuti dan jauh dari hoax atau berita bohong. Dimana Prabumulih Pos, melalui bukti versi koran cetak dan PDF, telah berkontribusi melakukan publikasi program ungulan sekolah rujukan sesuai dengan kode etik jurnalistik. 


\section{DAFTAR PUSTAKA}

Ade Putranto Prasetyo. (2020). Manajemen Media Massa Konsep Dasar, Pengelolaan, Dan Etika Profesi. Yogyakarta: Pustaka Baru.

Indonesia. (2011). Kamus Besar Bahasa. Jakarta: Republik Indonesia.

Kamaruddin, Kamaruddin. (2018). Manajemen Pers Pada Media Massa Dalam Era Reformasi (Studi Penyampaian Dakwah Islam). Jurnal Komunikasi Islam Dan Kehumasan (JKPI), 2(2): 127-46.

Mahfuzhah, Hannah, and Anshari Anshari. (2018). Media Publikasi Humas Dalam Pendidikan. Al-Tanzim: Jurnal Manajemen Pendidikan Islam, 2(2): 137-49.

Moloeng, Lexy. (2016). Metode Pendidikan Kualitatif. Bandung: PT. Remaja Rosdakarya.

Riza Fahlevi. (2021). Surat Keputusan Sekolah Rujukan Tahun Pelajaran 2021/2022. Palembang: Dinas Pendidikan Provinsi Sumatera Selatan.

Setiawan, Aria Aditya Setiawan Aria Aditya. (2013). Peran Media Massa Dalam Meningkatkan Kualitas Kepemerintahan Lokal Berbasis Human Security Di Kota Jayapura. Politika: Jurnal Ilmu Politik, 2(2): 39-48.

Somantri, Manap. (2020). SEKOLAH RUJUKAN (Studi Evaluatif Di SMKN 1 Kota Bengkulu). MANAJER PENDIDIKAN, 14(2): 92-109.

Sugiyono. (2017). Metode Penelitian Kuantitatif, Kualitatif, Dan R\&D. Bandung: Alfabeta, CV.

Usman, Husnita. (2020). Implementasi Kebijakan Sekolah Rujukan Di Smp Negeri 1 Taliabu Barat Dalam Meningkatkan Mutu Pendidikan. Universitas Muhammadiyah Malang.

Utomo, Prasetyo Budi, Mulyadi Eko Purnomo, and Mgs Nazarudin. (2021). Studi Perencanaan Manajemen Sumber Daya Manusia Tenaga Pendidik Di SD Islam Palembang. Studia Manageria, 3(1): 83-97.

Wicaksono, Kukrit Suryo. (t.t.). PERAN PERS DALAM PENINGKATAN DAYA SAING DAERAH.” Interaksi: Jurnal Ilmu Komunikasi, 4(2): 175-86.

KS. "Wawancara." SMA Negeri 2 Prabumulih, 2021.

AZ. "Wawancara.” Pemimpin Redaksi Prabumulih Pos, 2021. 
